\title{
Belgeo
}

Revue belge de géographie

3 | 2014

Art(s) \& Espace(s) / Art(s) \& Space(s)

\section{Beyond Bombay art district: Reorganization of art production into a polycentric territory at metropolitan scale}

Au-delà de l'art district de Bombay : Réorganisation polycentrique de la production artistique à l'échelle de la métropole

\section{Christine Ithurbide}

\section{OpenEdition}

\section{Journals}

\section{Electronic version}

URL: http://journals.openedition.org/belgeo/13199

DOI: 10.4000/belgeo.13199

ISSN: 2294-9135

\section{Publisher:}

National Committee of Geography of Belgium, Société Royale Belge de Géographie

\section{Electronic reference}

Christine Ithurbide, «Beyond Bombay art district: Reorganization of art production into a polycentric territory at metropolitan scale », Belgeo [Online], 3 | 2014, Online since 19 December 2014, connection on 19 April 2019. URL : http://journals.openedition.org/belgeo/13199; DOI : 10.4000/belgeo.13199

This text was automatically generated on 19 April 2019

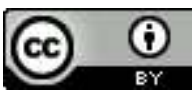

Belgeo est mis à disposition selon les termes de la licence Creative Commons Attribution 4.0 International. 


\title{
Beyond Bombay art district: Reorganization of art production into a polycentric territory at metropolitan scale
}

\author{
Au-delà de l'art district de Bombay : Réorganisation polycentrique de la \\ production artistique à l'échelle de la métropole
}

Christine Ithurbide

\section{Introduction}

1 The notion of the art district has been central to analyze the relations between arts and spaces, and more particularly to understand the recent evolution in the organization of contemporary art industry and practices in different urban contexts. Derived from the industrial district conceptualized by Alfred Marshall in the late $19^{\text {th }}$ century and revisited in the 1980s in Italy by the theorists of the regulation and, in particular Giacomo Becattini, it came to designate more or less concentrated area specialized in art activities, initiated either by small-scales industries or public institutions or both. Despite the diversity of origins (spontaneous or planed), settings (artisans' village, historical center, industrial landscape) and functions (productive, institutional, commercial) applied to the art district, the notion of geographical and sectorial concentration of the enterprises remains the basis of the model (Scott and Soja, 1996; Santagata, 2002; Mommaas, 2004; Pilati and Tremblay, 2007). Initially, art districts were valued as leading a process of urban and economic regeneration of neighborhoods. However, their contribution to the urban and economic development was nuanced because of their instrumentalisation by public policies and private actors for the purpose of gentrification, evictions and sometimes precarious employment ${ }^{1}$ (Bailey et al., 2004; Harris, 2005²). 
2 Another important feature of the art district, derived from the industrial district model, is more rarely studied. It concerns the integration of the district into networks of other districts at regional or national scale (Cadène and Holstrom, 1998). Hence, the art district presents itself as an element of an articulated system, networked with other specialized territories across the metropolitan region and beyond. Rather than focusing on the art district as the core of Bombay art territory, my approach highlights the evolution toward a polycentric intra-metropolitan configuration, shaped by a network of specialized neighborhoods. A particular focus is given to the establishment of connections with places and actors often situated on the urban, economic and social margins.

Situated at the crossroad of urban, industrial and social geography, the geography of art proposed is influenced by sociology of art (Becker, 1982; Moulin, 1992) and sociology of work in art (Menger, 2001 ; Roueff, 2014). It inherited certain debates at stake in cultural geography, especially one pointed out by Don Mitchell declaring that any cultural geography is a geography of power as it implies power relations with a sophisticated division of labor required for cultural production (Mitchell, 2000). The question of the division of labor in contemporary art industry at the metropolitan scale will be more particularly tackled in the third part of the article. Based on fieldwork surveys collected between 2010 and 2014, the method deployed relies primarily on qualitative data (semistructured interviews ${ }^{3}$, participant observation, production of location maps and mental maps).

\section{The making of a cultural metropolis (from 1850s to 1950s)}

4 Bombay contemporary art territory finds its origins in the morphological evolution of the city and its particular socio-cultural milieu developing from the colonial period to the 1950s. Besides introducing the first art spaces, actors and networks shaping Bombay art district, a broader approach of the cultural context of the city is presented in this part, including the development of photography, literature, theater, film and architecture. Such perspective aims at questioning to what extend Bombay can be considered as a cultural metropolis as early as the beginning of the $20^{\text {th }}$ century and how artists, artisans and art patrons contributed to it. Bombay's importance as a cultural crossroad and diffusion center is also discussed.

\section{The role of the entrepreneurial and cosmopolitan milieu in early cultural developments}

5 Bombay has long been the "New York" of India with world-wide commercial interests and a large resident cosmopolitan group ${ }^{4}$. Since the $18^{\text {th }}$ century, mercantile communities Parsees, Guajarati Banias and Jews settled in the city and started their businesses in ship construction, opium trade and cotton industries. A growing population of skilled-labors migrated to the city including goldsmiths, ironsmiths, weavers, potters and construction workers (Dwivedi and Mehrotra, 2001). Within a few decades, the industrial revolution transformed Bombay into India's most modern city in terms of manufacturing, finance and services (Patel and Throner, 1995). The collaboration between British and Indian entrepreneurial elites has been essential, not only to build Bombay's prominent economic 
position, but also to the emergence of the city as a cultural metropolis ${ }^{5}$. It is in the particularly innovative and philanthropic atmosphere of the second half of the $19^{\text {th }}$ century that Bombay developed as a new center for photography, press, literature, theater, film industry and art.

6 First Indian city to have a Photographic Society in 1854 and second after Calcutta in its number of photography studios, Bombay was one of the main locations from where photography spread throughout the rest of the subcontinent (Jain, 2007; Rahaab, 2010). There were almost ten thousands printers, lithographers and engravers in $1911^{6}$. The press industry though in its infancy was flourishing with dozens of magazines in English, Gujarati and Marathi illustrated by painters and Bombay was one of the most important centers of modern Gujarati literature (Patel and Throner, 1995). Artists started to publish art journals in different regional languages such as Visri Sadi (1916) and Kumar (1924)7. In 1863 , the British government redeveloped a cemetery into an entertainment district named Pila House with a dozen theaters. Jamshedjee Jeejeebhoy School of Art (J.J. School of Art) named after its Parsee founder was a focal point for arts education in western India, attracting painters and sculptors from all parts of the country (Sadwelkar, 1996). The creation of the Victoria \& Albert Museum (1855-72) ${ }^{8}$ became emblematic of the increasingly cosmopolitan character of such cultural projects as the greatest merchants from Hindus, Muslims, Christians and Parsees communities contributed to its foundation. Hence, the economic success of the industrial revolution was not disconnected from the emergence of these new cultural structures. Textile entrepreneurs invested their benefits in the development of cinema industry. The first Indian film was produced in Bombay in 1897 and from 1913 to 1938, the number of film production studios in the city was multiplied by ten (Gangar, 2003). The establishment of a great number of other pioneering institutions in education, geography or medicine, between 1822 and 1857, led the historian J.V Naik (1995) to qualify Bombay of urban centre of enlightenment and learning.

The development of cultural institutions and industries was taking place within a larger urban plan: the redevelopment of Fort area into a cohesive city center (Mehrotra, 1998). With land unifications, fortification dismantling and ambitious architectural projects, South Bombay transformations were comparable to Napoleon's III rebuilding of Paris (London, 2003 ; Harris, 2005). This redevelopment was characterized by the division into specialized sectors dedicated to trade (Ballard Estate), bank (Horniman Circle) or recreational activities (Oval Maiden). The little Horny Row where many influential Parsees lived was metamorphosed into Hornby Road, a prestigious commercial avenue with Gothic Victorian style architectures that make today the reputation of the city. In this enterprise, European engineers associated closely with local engineers, sculptors, artists and craftsmen who left their marks on the design they executed (Chopra, 2011). The incorporation of both European and Indian styles aimed at emphasizing Bombay as a metropolis of international standing.

Bombay appeared as a centre of innovation and diffusion across India and Asia. During the 1920s, with the emergence of Indo-Deco or "art dekho" style (Windover, 2009), the city contributed to an Eurasian Art Deco movement spreading to other cities in Asia, such as Java and Shanghai (Delalande, 1995 ; Hamonic, 2007). At national scale, businessmen and leaders of different regions (Rajasthan, Kutch) visiting Bombay would discover new artistic and architectural trends and reproduce them in their houses or city public buildings (Dwivedi and Mehrotra, 2001). Nevertheless, if the residences of Indian elite 
displayed an increasingly cultural syncretism, the homes of the poorest sections had sporadic traces of European influence, underlying a cultural globalization at two speeds. Most migrants' workers were living at the margin, both spatially and culturally (Patel and Throner, 2003).

\section{Shaping an art centrality in Fort, South Bombay}

9 During the first half of the $20^{\text {th }}$ century, Fort emerged not only as an administrative and commercial center but also as an artistic centrality (Figure 1a). Art societies, schools of art, exhibition hall and museums were located in this neighborhood. This artistic apparel was mainly built by the British and Indian elite for their own use and near their residential area (Harris, 2003). Interestingly, this situation provided a challenging tool for local creativity, leading to the invention of new structures (Hannerz, 2010). For instance, the Bombay Art Society exhibitions were hardly accessible to Indian artists who had to be members to enter them (Sadwelkar, 1996). Hence, in 1918, renowned Indian painters founded The Art Society of India to promote Indian artists only. Progressively, other spaces were opened by the non-elite in northern neighborhoods of Bombay, such as the Haldankar's Fine Art Institute (1908) and the Model Art Institute (1939) in Dadar. A similar process happened in theater when tin-shed theatres mushroomed outside of Pila House district, breaking the upper casts monopoly of theatre entertainment (Gangar, 1995).

10 At the post-independence (1947), a particular neighborhood in Fort area named Kala Ghoda, began to established as an institutional, commercial and intellectual artistic center (Figure 1b). It gathered the most important art institutions and exhibition spaces: the Prince of Wales Museum (1901-14), the Cowasji Jehangir Hall (1911) and then the Jehangir Art Gallery (1951), to which the National Gallery of Modern Art was added in the 1980s. It is also where the artworks of the emblematic Progressiv Artists' Group were displayed, shaping Kala Ghoda as the symbolic epicenter of the nascent Indian contemporary art world 9 . The opening of the two firsts commercial art galleries Chemould and Pundole prefigured the emergence of this area as an art market hub. Art edition house Marg, libraries (Chetana Centre) and the Artists' Aid Fund Centre contributed to the intellectual vibrancy of the neighborhood. Arguing that Bombay artists needed space to stay, V.N Nadarkar the director of the J.J. Applied Art School asked the municipal government in 1962 to build an artists' colony. Kala Nagar was constructed on wetlands in Bandra East, considered at that time an unwanted land in the North of the city. This project prefigured the migrations of numerous artists from South Bombay to the suburb. Indeed, despite the magnet effect of South Bombay in the 1960's, a more fragmented geography of art progressively emerged in the immense and developing northern region of the city and its suburb.

\section{The institutionalization, expansion and limits of Kala Ghoda Art District}

11 From 1950 to 1980, Bombay experiences radical changes in its demographic and industrial context. New neighborhoods are planned in the surburb to face the demographic pressure that follows Independence ${ }^{10}$. Industrial activities start to be relocated from south and central districts such as Parel and Dadar to Andheri, Thane and Navi Mumbai in 
the suburb. The international airport is constructed in Andheri and the new central business district (Bandra Kurla Complex) is created nearby at Bandra East. While employments in manufacturing keep declining after the 1980s, replaced by trade, service and finance, cotton mills are converted into malls, design boutiques and restaurants leading to the increase of reserved spaces dedicated to lifestyle and consumption of the elite (Chatterjee, 2006). This process happened in parallel of important economic liberalization reforms. New private actors emerge and among them, collectors (director of corporate, IT worker) and art traders (art consultant, gallery manager, auction house director) got involved in the art business, leading to the boom of the art market in the 2000 's. It is in this urban and economic context that the territorial reorganization of contemporary art activities and production happened (Figure 1c).

Figure 1. The development of art spaces in Bombay from 1850 to 2011.

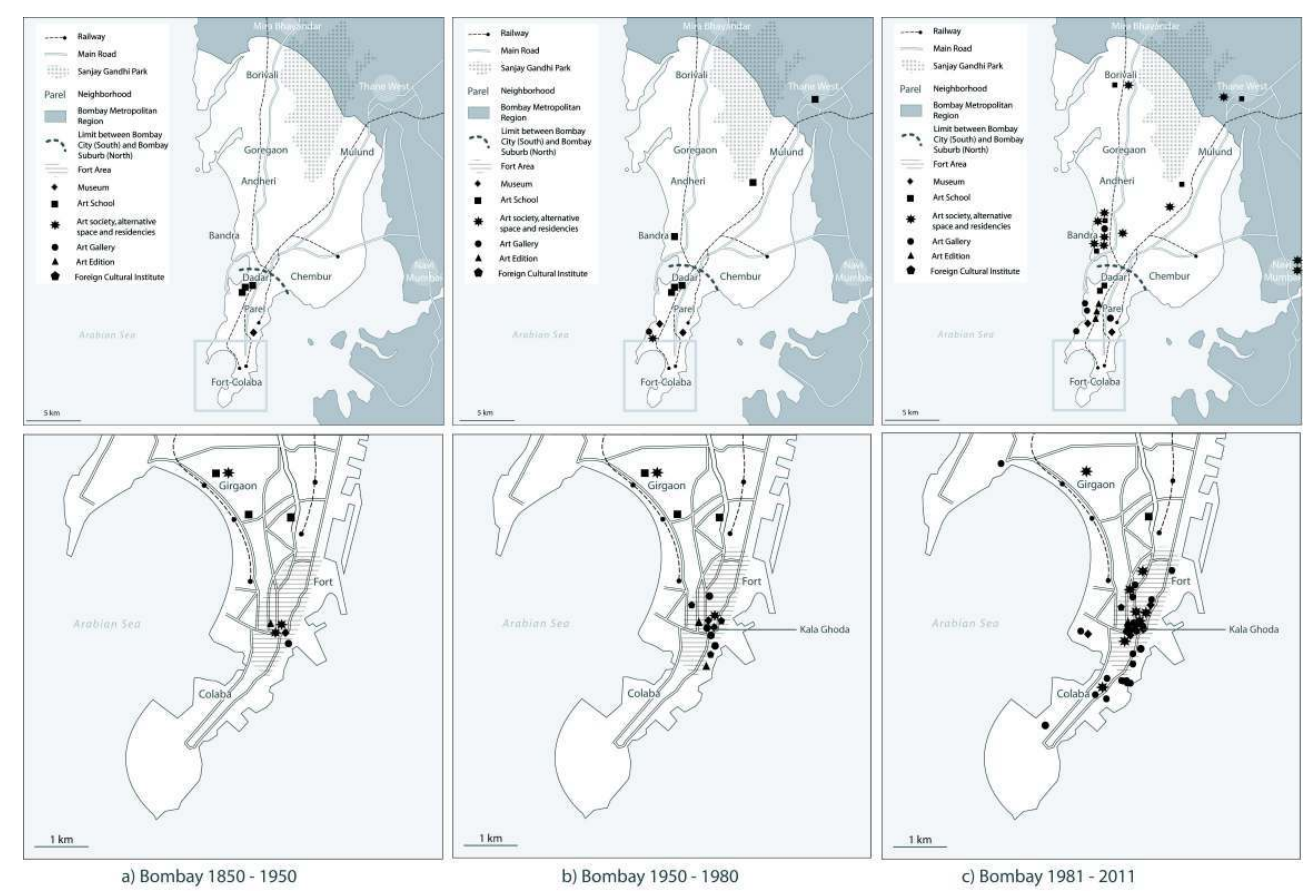

Conception and sources C. Ithurbide 2014

\section{Kala Ghoda Art District, the SoHo of India}

The 1990s marked the consecration of Kala Ghoda as the first art district of India (Figure 2). The very idea of identifying Kala Ghoda as an art district arose from the pioneering work of the historian Dwivedi and the architect Mehrotra (Hoskote, 2012). With a combined total of almost 110,000 sq.ft of existing indoor gallery space, the Kala Ghoda crescent had an existing critical mass of art galleries, museums and cultural spaces that was unrivalled in all of India and comparable to art districts in other part of the world (Mehrotra et al.). Far from being an artist-led regeneration process or a public redevelopment plan, the actors behind the Kala Ghoda art district belonged to the civil society including urbanists, journalists, conservationists and area's key stakeholders (Tata, Jindal Enterprises). They formed the Kala Ghoda Association in $1998^{11}$. 
Figure 2. Kala Ghoda Art District in Fort, South Bombay.

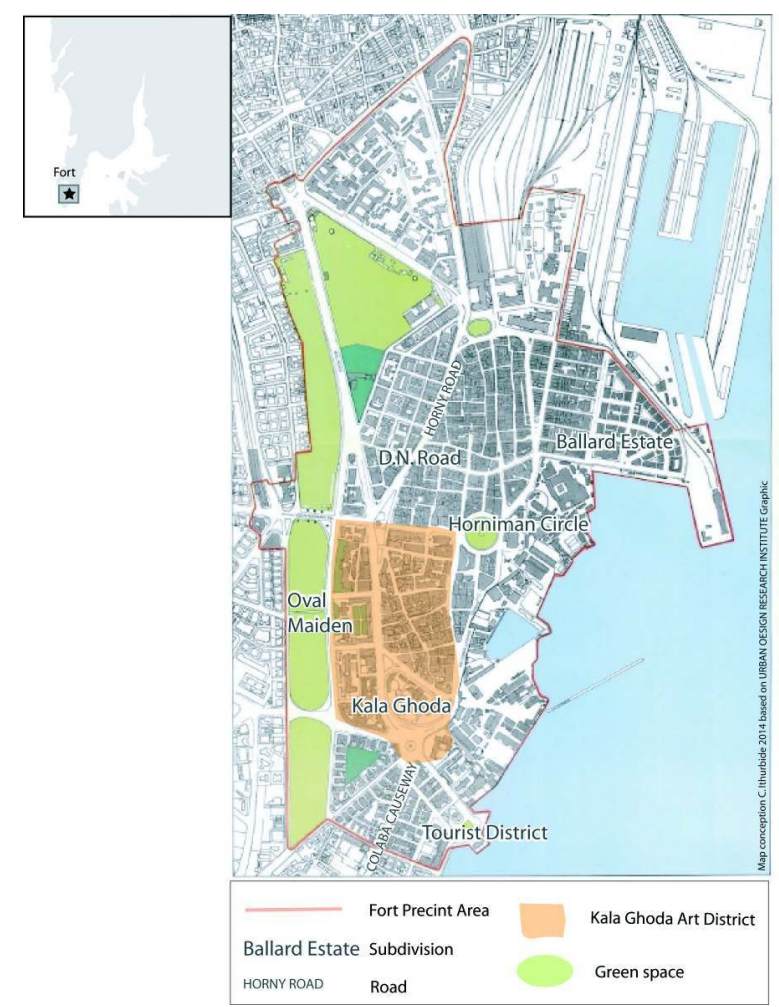

CONCEPTION C. ITHURBIDE 2014, BASE MAP gRAPHIC UDRI. processes: gentrification, with international brands replacing local shops, and beautification of streets and avenues often accompanied by eviction of beggars and street sellers (Harris, 2005). Those two processes spread beyond Kala Ghoda on Colaba Causeway area. Arthur Bunder Road, formerly known to be a place of prostitution and drugs turned into an art street. The businessman and political leader Abu Farhan Azmi, who owned major buildings on this road started to rent the high ceilings spaces of former warehouse and old Mansion to gallery owners and designers. Kala Ghoda and by extension the north of Colaba became the Soho of India both in the media and in collective imagination. Ghoda - Colaba with about thirty contemporary art galleries, dozens of design stores and three auction houses. Only a few alternative spaces (Mohile Parikh Centre, Mumbai art Room, Clark House Initiative and Studio $\mathrm{X}$ ) were able to stay in this expensive neighborhood. Some galleries previously located in northern parts of the city like Sakshi Gallery in Parel and Lakereen in Vile Parle, moved in this area. Art galleries consist in small enterprises with one manager, often a woman, who studied art history and curating abroad, and two or three English speaking assistants. They rely both on local and international buyers, either foreigners or Non Resident Indians. The rehabilitation of warehouse (by Project 88, Maskara Gallery), or the restoration of trade building (by The Guild, Volte, Chemould) into white cubes inscribed even more clearly the art district into a global art trend. Clustering together established a relationship of cooperative-rivalry allowing information exchange and the use of the same services (Benko and Lipietz, 1992). A former student at J. J. School of Art explains that for instance most of the art 
galleries go to the same framer shop, Chenaram. "All use the same technicians in electricity, wall building and painting for their scenography" adds Sharma, founder of an alternative space.

This spatial proximity became also a strategy to reach international visibility. In the absence of active public art institutions, western curators and responsibles from art biennale interested by contemporary Indian artists would visit South Bombay galleries to discover and select artists. Their focus on large scale installations and their commission for international shows accelerated the need for artists to find new spaces of productions and specialized technicians to produce more ambitious projects. In 2011, after the market recession, ten galleries in Kala Ghoda-Colaba associated to form The Mumbai Art District and organized monthly art nights (Thursday Art Night), as a way to redraw the boundaries of Kala Ghoda Art District and to be placed at the center of the urban artistic centrality.

16 Kala Ghoda Art District contains its own hierarchy. Working in the shadow of the art market, numerous small enterprises contribute to the art industry. Among them, framers shops cluster at the end of Colaba Causeway. Mohan, 41, left his village in Rajasthan when he was 12 to come to work in Bombay. He started as framer assistant on Colaba Causway and opened his own shop in 2005 where he employs four persons. Despite its small size, the enterprise has adapted to global market context. "When I started, I got good quality of wood from India. Now I buy my material to a supplier based in Andheri who imports wood and fiberglass from China. It is synthetic, already colored imitation wood. It just has to be cut and assembled". Mohan works for an auction house of Fort and the Jehangir Gallery and feels part of this Art District. Whatever their place in the social and economic hierarchy of the art district, most art entrepreneurs need to articulate with other specialized spaces and networks of actors beyond the art district.

\section{The effect of the professionalization and diversification of art industry: toward a discontinuous and polycentric territory}

17 This entry into international circuits implied a series of structural adjustment and required the professionalization and diversification of the art activities: edition, curating, exhibition design, art management, art transport etc. What have been the effects of this development on the reorganization of the art territory at the metropolitan scale? The mapping of the different sectors of the art industry highlights two important points: similar activities tend to gather in the same neighborhoods and a wide range of activities happen outside South Bombay (figure 3) ${ }^{12}$. There is a concentration of commercial and institutional activities in Fort, editing in Lower Parel, art management and alternative spaces in Bandra, art transport in the industrial area of Andheri West. Their location can be explained by specific urban contexts (Scott, 2006). For instance, Lower Parel has been the heart of textile industry and the place of the greatest strikes against mills reconversion into business offices. In the 1990s, Lower Parel became a district of services with numerous consulting, communication and advertising agencies. Offices specialized in art and design edition occupy the same tower than the corporates who own them (Art India in the building of JSW Steel, Domus in Spenta Multimedia). Multiple personal and professional links bound together South Bombay commercial spaces and the editing world of Lower Parel as art critics report often on gallery shows and may be asked to 
curate exhibitions. Those networks also enabled to structure a stronger art scene, critically and scientifically.

Figure 3. Art Industry in Bombay.

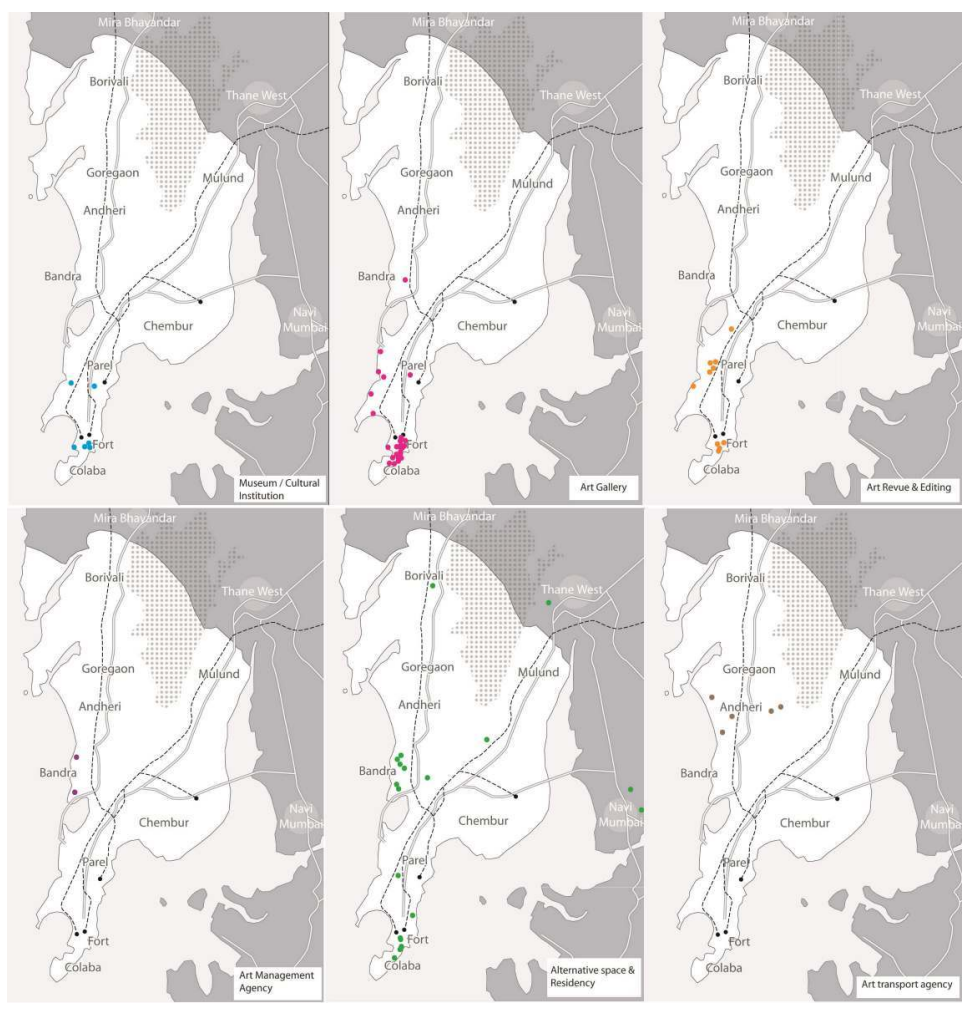

Conception and sources C. Ithurbide 2014

West, highly appreciated by upper classes, expats and young creative generation, tends to be a unique mix between an on and off district. It has no museum or commercial art gallery but numerous alternative art forms such as graffiti and street art. Started in 2007, the artists collective CAMP embodies a radical off attitude and aims at being a countermodel of the South Bombay galleries: a non-commercial space for community projects managed by practicing artists, shut away from art scene and resisting to facebooking. Since 2010, two art management agencies opened in Bandra also. What about art? occupies two floors of a building that will be soon redeveloped and her manager transformed the emptied apartments into artists' studio residencies. Started in a coworking space, the dynamic Art Asia Project, created the first edition of a photography festival across the city in 2013. At the frontier between Bombay city and its suburbs, Bandra West highlights increasingly polycentric dynamics with new actors to activate the linkages between the different segments of the city.

A new generation of artists collective aims at revitalizing Bombay suburb, poor in artistic spaces and events. It is the objective of Cona in Borivali, founded in 2012. "We are looking at extending our art spaces towards the North, there are immense possibilities for new projects. It's time that there is change and shift in the dynamics of the city, geographically, economically and socio-politically" the founders Hemali Bhutta and Shreyas Karle claim. In 2013, two more collectives and transdisciplinary organisation started in Navi Mumbai, The Centre for Arts and Social Practice and New City Limits. In 
response to the creation of The Mumbai Art District by commercial art galleries, the founders of the different alternative spaces in the city considered creating their own networks and formed Umbrella, a group of non-commercial art spaces and collectives in Bombay. If there was a real enthusiasm around this idea, it was more complex to implement because, unlike galleries, they are located in very different parts of the city from Colaba to Borivali and the constraints of distance and transportation have been a real obstacle. Nevertheless, an online bookstore is under-construction, highlighting the role of the web in the production of new types of art territories.

The recent involvement of corporates in art may also contribute to redraw Bombay art territory. Situated in the industrial area of Vikroli, Godrej corporate chose to open its think-tank the Godrej India culture Lab in this location, fulfilling the will to be geographically somewhere else than South Bombay to create an alternative intellectual hub in the city. On the side of the public sphere, hardly any initiative for the development of art institution in the suburb is to be expected. According to the Town Planning Department of Thane Municipal Corporation, a museum was to be open in Thane to create a northern branch of the South Bombay CSMV museum (former Prince of Wales Museum), but the project was abandoned after the change of Municipal Commissioner.

The map analysis confirms the evolution of the organization of art industry toward a discontinuous and polycentric spatiality. During the last decade, in superposition with broader urban development, new artistic "out-of-core centers" emerged (Van Criekingen et al., 2007). They represent specialized territories in art trade and services, superimposed to certain portions of the urban space, a structure made possible because of specific urban context and multiple actors strategies (Bautès, 2004).

\section{New territories of art production: Bombay suburb and beyond}

One of the effects of the success of Indian artists internationally was the evolution of the webs of production, in other words, the relocation of studio spaces and the reorganization of production system. Such process is embedded in other mutations: the increase of the rent cost in most of the neighborhoods of the city, the rise in the number of commissions for monumental installations and the desire to produce technically challenging artworks. Continuing to highlight the role of "out-of-core centers" in Bombay contemporary art territory, this part analyzes the networks of collaborations constructed by artists especially with skilled workers and fabricators from small enterprises.

\section{The "Other Bombay" or the territories of practicing artists}

When I asked him to draw his mental map of Bombay art territory, Shreyas Karle divided in two parts the sheet of paper with an horizontal line, naming the one below SoBo (South Bombay) and the upper one OsBo (Other Bombay). "One side for galleries, the other for artists' studio" he explains (Figure 4). While the South of the city is associated with commercial and institutional activities, the conception and production of artworks happens in the suburb of Bombay (Goregaon, Borivali). Today, an increasing number of artists consider going even further, in cities located in Bombay metropolitan region such as Mira or beyond Navi Mumbai in Kalyan, Kamote or Kharghar. 
Figure 4. Shreyas Karle mental map Bombay art territory (March 2013).

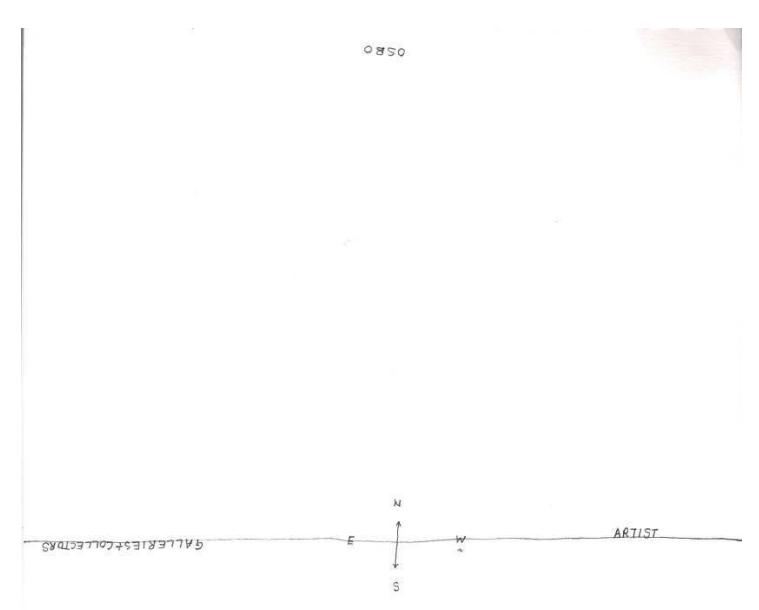

Borivali neighborhood is known as the "Little Kerala" of Bombay in the artists' community. "Important painters of Kerala origin settled here in the 1980's, followed by a second generation in the 1990s with Riyas Komus, Bose Krishnamachari and TV Santosh, and finally my generation arrived" explains Sujit, a young painter who lives and works at the $7^{\text {th }}$ floor of a residential building in Borivali. But because of the market crisis affecting his sales, he plans to move out of Bombay Suburb where it is cheaper - for now. Senor artist Sudhir Parthwardan explains that apart from those who are born in Thane, only a small handful of artists have now the means to buy a studio here and maintain it. "For the people and artists living in Thane, Fort-Colaba is the suburb", declares young artist Rupali, rightly questioning what being in the "periphery" means today. Isn't it precisely artists' community who should represent the heart of the art system? Or has the marketdriven-world in which Bombay entered managed to erase this aspect?

While most artists share the same room for living and working, the generation of artists who became successful during the market boom from 2002 to 2008, managed to acquire bigger studios or warehouse in the industrial area of Andheri, Mulund or Thane. Some of them have different spaces for each steps of their production: one studio for the administrative, research and development tasks, one warehouse for fabrication and assembling, and one space to stock the artwork. But quite often, for economic or technical reasons, Bombay artists cannot have their work done neither in their studio nor in the metropolitan region. They travel for a couple of weeks outside of Bombay where studios and production facilities can be more easily available and less expensive. The city of Baroda, in the neighbor state of Gujarat, is a popular destination because of its relative proximity with Bombay ( 5 hours by train) and the dynamism of the art department at M.S University. During the art market boom, several entrepreneurs in construction or 
industry started to dedicate one branch of their activity to art production. In 1999, Manish Maheshwari created Rachaita Creative Solution in the industrial estate of Baroda and has been helping important Bombay artists such as Sudarshan Shetty or Riyas Komu.

Contemporary art today is a science of space engineering that requires reaching and articulating different intervention areas (Volvey, 2013). It is precisely the challenge of most contemporary Indian artists today. Valay Shende's studio is located in Andheri industrial area. Born in 1980 in Nagpur (Maharashtra, India), he graduated from J.J. School of Art in 2004, has his first solo show at Sakshi Gallery (Colaba) in 2007, participated to several art fairs (Dubai, 2008, Beijing, 2009) and art exhibitions including Indian Highway, Lyon in 2011. Valay explains that his studio is the central node of his activity network. It is a place of conception, design and manufacturing of his work. Inside his studio, several assistants work on his projects. Most of them migrated from the same region than him and used to work in automobile industry and machine repairing before he trained each of them. From this centrality, the artist makes connections with different areas located in the north and south of the city (his home, his stored room, his fabricator, his gallery etc.). "Finding a good place of production is difficult" Valay says. His early sculptures were casted in Gujarat, the production cost was cheaper, but he had to stop due to quality problems and delay in production. "Artists need good fabricators to maintain good production quality but the links miss between artists and people with good machines. Besides, India needs to import more high quality machines" he adds. One of his artist friends had to go to China to find a foundry capable to melt a monumental bronze sculpture for a commission. "Chinese workshops have the ability to melt very large sculptures, not like those currently existing in India". As many other India artists, Valay increasingly needs to articulate multiscale spatiality in his production.

\section{Integrating spaces and networks from the margins}

Following Becker's approach, my study aims at replacing the artist at the center of a network of cooperation with actors who all perform a vital job to the completion of the artwork (Becker, 1982). As suggested in the previous examples, the production process in contemporary art is involving an increasing number of little hands: unskilled labor for repetitive tasks, studio assistants, artisans in wood or stone carving, skilled-labor (in metal, electricity, for molding, casting, assembling..), and collaborations with different types of industrial specialists from architects to laser engineers. To what extent the analysis of those collaborative networks enables to explore new spatial connections with neighborhoods usually considered in the margin or outside the art world? This dimension questions once more the boundaries of the art territory of Bombay.

The collaboration between artists and small-scale industries located in neighborhoods such as Dharavi or Malad focused the attention of my last fieldworks (2013 and 2014). Designated as slums, both neighborhoods are before all massive manufacturing centers where people are living and working in very hard conditions. They unveil thousands types of workshops specialized in all the thinkable types of skills-labors: from pottery, leather, bangle makers, to the immense recycling industry in plastic, cotton, glass, copper wire, shoe soles, cardboard etc. Unlimited possibilities for collaboration and outsourcing for art production can be found here. Vijay belongs to a family of idol makers and during the off season, he is artist's assistant. He lives in Malad and knows where to find the appropriate skilled-worker in this maze of small-scale industries where almost any object 
can be made in great number. This time, he found a place where about one hundred wooden pieces could be sculpted and painted for the artist's final installation. Skilledworkers are often asked to fabricate objects they never made before, they have to find out the solution, be creative and improvise with the time, material and skill they have. While they are not considered to be part either of the "creative class" or "artist" category, they nevertheless contribute to the art production system. The territorial approach of the art scene enables to integrate them as part of the contemporary art space.

Several Indian artists, exhibited in major international retrospectives (Century City, 2001 in London; Chalo India!, 2009 in Tokyo; Paris-Delhi-Bombay, 2011 in Paris etc.), acknowledge the importance of those invisible actors, of this "grey" sector which exist in almost every neighborhoods of Bombay. Sudarshan Shetty explains that he gets inspired a lot by people involved in small industries for his work. "They use what I call street technology; I always try to appropriate those interesting elements into my work" (Fontanella-Khan 2010). The capacity shown by those unorganized spaces to improvise becomes a source of inspiration and tends to produce a creative atmosphere. Sudarshan has been also outsourcing parts of his art production to a fabricator located near Parel neighborhood in Sewri (Gehi, 2014). Ajit, the fabricator, has become a vital means of production for many artists of the city. Relying on his own subcontractors network, Ajit came to delegate certain tasks in production to specialists who take care specifically of the casting or motorized systems for instance. There are no written contracts, everything is based on confidence. Another artist who was invited at the Paris-Delhi-Bombay show explains that she can do things in Bombay that are not possible in Paris ; "it's more complicated in Paris as it is a more organized sector. In India, we find flexible factory production, it's better when it is not organized!". In his studio located in Fort, Sunil Gawde tells about the importance of his collaboration with his fabricator from Andheri involved in the production of his masterpieces, including Alliteration, exhibited at the Venice Biennale in 2009. "They are so many small scale industries, but one needs to know how to channelize them" he adds.

30 If the contributions of small scales industries to Indian cultural industries are better known in the design, fashion and film production ${ }^{13}$, it remains an unexplored field in the case of contemporary art production. This first attempt to explore those collaborations shed a new light on the composition of Bombay art territories, with the superposition of different typology of spaces : institutional / informal, organized/unorganized, visible / invisible, all inextricably entangled and evolving within local, urban, and international dynamics.

\section{Conclusion}

31 Few studies have been conducted on the organization of contemporary art industry and practices in Indian cities (Bautès, 2004; Harris, 2005), and more particularly on their reorganization following the insertion of the Indian art scene in the global system in the late 1990's. This article has presented the evolution of the territorial organization of the contemporary art scene in Bombay focusing on the networks dynamics of this system and the articulations of activities beyond the art district. Two opposite movements centrifugal and centripetal have been observed. On the one hand, the strengthening of the artistic centrality of South Bombay produced by the concentration of new spaces in Kala Ghoda and Colaba was accompanied by increasing institutional and commercial 
functions. On the other hand, the development of specialized services (editing, consulting, art management, art transport), related to the insertion of Bombay art scene in a global art system, marked the advent of a discontinuous and polycentric territory in the Indian metropolitan area. Such approach put into question the territorial hierarchy imposed by the idea of the "art district" reduced to commercial function. Indeed, despite its fragmented spatiality, the "Other Bombay" (suburb) emerges as a place of art production and innovation with increasingly complex networks tighten with actors and spaces usually considered at the margin of the art world. Different processes of redrawing the boundaries of the art territory are being initiating and may conduct, with or without institutional support, to a more inclusive and participative geography of art.

\section{BIBLIOGRAPHY}

AMBROSINO C. (2011), « Quartier artistique, territoire créatif », in BELLAVANCE G., ROY-VALEX M. (dir.), Arts et territoires : vers une nouvelles économie culturelle? Québec, Presses de l'Université Laval, coll. Questions de culture.

BAILEY C., MILES S., STARK P. (2004), "Culture-led urban regeneration and the revitalisation of rooted indentities in Newcastle, Gateshhead, and the North East of England", International Journal of Cultural policy, 10, 1 .

BAUTES N. (2004), Le goût de l'héritage. Processus de production d'un territoire touristique : Udaipur (Rajasthan, Inde), thèse de doctorat soutenue à l'Université Paris 7-Denis Diderot le 14 décembre 2004.

BECKER H. (1982), Art Worlds, University of California Press.

BENKO G., LIPIETZ A. (1996), « Les districts industriels revisités », in PECQUEUR B. (dir.), Dynamiques territoriales et mutations économiques, L'Harmattan.

CADENE P., HOLMSTROM M. (1998), Decentralized production in India, Industrial Districts, Flexible Specialization and Employment, French Institute of Pondichery and Sage Publication.

CHATTERJEE P. (2006), “Are Indian Cities Becoming Bourgeois at Last?”, in JOHN M.E., JHA P.K., SURINDER JODHKA S. (ed.), Contested Transformations : Changing Economies and Identities in Contemporary India, Tulika, New Delhi, 2006.

CHOPRA P. (2011), A joint enterprise, Indian Elites and the Making of British Bombay, University of Minnesota Press.

DELANDE N. (1995), « Décor-déco : Shanghai 1920-1930 », Perspectives chinoises, 30, pp. 46-52.

DWIVEDI S., MEHROTRA R. (1995), The cities Within, Bombay, India Book House.

FONTANELLA-KHAN A. (2010), "Mumbai-based artist Sudarshan Shetty talks traffic, dystopia and trucks", CNN Travel, April $16^{\text {th }}$.

GRESILLON B. (2002), Berlin, métropole culturelle, Belin, Paris.

HAMONIC G. (2007), « L’Art Déco en Indonésie, Un imaginaire de la modernité » Archipel, 73, Paris, pp. 59-109. 
HANNERZ U. (2010), La complexité culturelle : études de l'organisation sociale de la signification. Bernin, À la croisée.

HARRIS A. (2005), Branding urban space: the creation of art districts in contemporary Mumbai and London. Thesis, University College of London.

HARRIS N. (2003), "Bombay in the global Economy", Methaphor for Modern India, Patel and Throner, Bombay, Oxford India Paperbacks.

HOSKOTE R. (2012), “City as Palympsest”, Outlook India, 27 February.

HUTTON T. (2009), “Trajectories of the New Economy: Regeneration and Dislocation in the Inner City", Urban Study, 46, 5-6, pp. 987-1001.

JAIN J. (2007), Indomania, l'art populaire indien, Lille 3000.

KONG L., O'CONNOR J. (2009), Creative economies, creative cities, Asian-European Perspectives, The Geojournal Library, 98, Springer.

LONDON C. (2002), Bombay Gothic, Bombay, India Book House.

MARTIN R., SUNLEY P. (2003), “Deconstructing clusters: chaotic concept or policy

panacea?", Journal of Economic Geography, 3, 1, pp. 5-35.

MEHROTRA R. (1998), “Bombay urban landscape: Evolution, Involution and the City's Futur, A perspective in Bombay's Urban Form", Marg, 49, 1.

MEHROTRA R., PAREKH A., TURNER T., LAMBAH A.N., HAZRA R., UDANI H, Kala Ghoda Art Crescent, Project Report for Physical improvements \& Budgetary estimates, Kala Ghoda Association \& Urban Design Research Institute.

MENGER P.M. (2001), “Artists as workers: theoretical and methodological challenges”, Poetics, 28, pp. 241-254.

MITCHELL D. (2000), Cultural Geography. A Critical Introduction, Oxford, Blackwell.

MOMMAAS H. (2004), "Cultural clusters and the post industrial city”, Urban Study, 41, 3.

MOULIN R. (1992), L'artiste, l'institution et le marché, Paris, Flammarion

NAIK J.V. (1995), “The seed Period of Bombay's Intellectual life 1822-57”, Bombay: Mosaic of Modern culture, Patel and Throner, Bombay, Oxford University Press.

PATEL S., THRONER A. (1995), Bombay: Mosaic of Modern culture, Bombay, Oxford University Press.

PATEL S., THRONER A. (2003), Bombay: Methaphor for Modern India, New Delhi, Oxford India Paperbacks.

PILATI T. et TREMBLAY D.-G. (2007), « Cité créative et District culturel ; une analyse des thèses en présence », Géographie, économie, société, 9, 4, pp. 381-401.

PRATT A. (2009), “Urban Regeneration: From the arts 'feel good' factor to the cultural economy: A case study of Hoxton, London", Urban Studies, 46, 5-6, pp.1041-1061.

RAHAAB A. (2010), "From Bombay to Mumbai, Studios of the City", The artful Pose, Early Studio Photography in Mumbai, 1855-1940, Mehta, Mitter (éd.), Bhau Daji Lad Alkazi Collection, Mapping Publishing Ahmedabad.

ROUEFF O. (2014), « La grandeur de Manet », La vie des idées (revue en ligne), 18 mars 2014.

SADWELKAR B. (1996), Contemporary Indian painters associated with Jehangir Art Gallery, Bombay, The Gallery. 
SAGLIO-YATZIMIRSKY M.-C. (2001), « Mumbai : Mutations spatiales d'une métropole en expansion », Mappemonde, 62, pp. 26-31.

SANTAGATA W. (2002), "Cultural districts, Property and sustainable Economic Growth", International Journal of Urban and Regional Research, 26, pp.9-23.

SCOTT A.J., SOJA E.W. (1996), The City: LA and Urban Theory at the End of the $20^{\text {th }}$ Century, Berkeley, University of California Press.

SCOTT A.J. (2006), “Creative cities: conceptual Issues and policy questions”, Journal of Urban Affairs 28,1 .

VAN CRIEKINGEN M., BACHMANN M., GUISSET C. et LENNERT M. (2007), “Towards polycentric cities. An investigation into the restructuring of intra-metropolitan spatial configurations in Europe", Belgeo, 1, pp. 31-50.

VOLVEY A. (2012), Transitionnelles géographies : sur le chemin de la créativité artistique et scientifique, Mémoire d'HDR, Tome 2, Université Lyon Lumière 2.

WINDOVER M. (2009). “Exchanging Looks : 'Art Dekho' Movie Theatres in Bombay”, Architectural History, 52 pp 201-232.

\section{NOTES}

1.

On the other hand, the term of "district" itself is controversial. As stated Martin and Sunley (2003), the district remains an unclear idea and refers to widely varying scales. Applied to the world of culture, geographical inaccuracy is doubled with a functional confusion (Ambrosino, 2011).

2. See also the issue Urban Studies, $46,5 / 6$.

3. This article is based on my $\mathrm{PhD}$ research (Geography of contemporary Indian art : cities, actors and territories. The case of Bombay (India) - Paris Diderot University, 2015) which encompasses 250 interviews in 10 different cities in India including about half of them in Bombay. References to interviews cited in this articles include : Geeta Mehra, gallery owner (Feb 2012, Bombay), Sudarshan Shetty, artist (Apr 2012, Bombay), Sujit S.N, artist (March 2013, Bombay), Vijay artist assistant (April 2013, Bombay), Sumesh Sharma, curator (March 2013), Shilpa Gupta, artist (March, 2013, Bombay), Prajakta Potnis, artist (March 2013 and Feb 2014, Bombay), Sunil Gawde, artist (March 2013 and Feb 2014, Bombay), Hemali Bhuta \& Shreyas Karle, artists (March 2013 and Feb 2014, Bombay), Valay Shende, artist (Feb, 2014, Bombay), Project assistant (Feb, 2014, Bombay), Sudhir Parthwardan, artist (Feb, 2014, Thane), Mohan and Vinod Solanki, framers (Feb, 2014, Bombay). In some rare cases, the anonymity of the persons interviewed is deliberately preserved or their name replaced.

4. Quotation from the Review of American Cultural activities in India, 1957, Jan 1955-July 1957, Inter-National Cultural Center, c/0 Indian Cooperative Union.

5. The tree mains features presented by Boris Grésillon (2002) will guide this demonstration: the concentration of the press, publishers, museums, universities and schools; the redevelopment of certain neighborhoods, prestigious avenues deserving the will to faire peau neuve; and finally the ever-increasing population growth.

6. According to the 1911 Census there was 9751 printers, lithographers and engravers in Bombay City. 
7. See Vasvi Oza presentation during the colloquium "Locating Art Histories", February 14-15, 2014 at the School of Arts and Aesthetics Auditorium, JNU, New Delhi.

\section{Renamed Bhau Daji Lad Museum in 1975}

9. It must be noticed that the preponderance given to the PAG in the writing of the history of Indian art, has contributed to the relative deleting other regional initiatives developed in parallel. In recent years, however, we see the rewriting of this great nation's history through research taking greater account of regional movements and marginalized art forms. A new geography of early modern art emerges, supported by a generation of art historians.

10. Its population increased from 2,3 million in 1951 to 4,1 million in 1961 and 8,2 million in 1981 due to flows of migrants from the Partition with Pakistan and with seasonal labors (Saglio -Yatzimirsky, 2001).

11. Other civil associations in different sub-districts of Fort (Ballard Estate Welfare Association, Land Hormiman Circle Assocation) existed since the 1980s to defend specific conservation or redevelopment project.

12. To make an inventory of the locations of contemporary art activities is a pioneering work in the case of Bombay.

Unlike other cultural industries such as film, there is no professional directory. A list of the different sectors belonging to the contemporary art industry was established based recent literature on cultural industries (Kong et O'connor, 2009). An inventory of businesses for the different sectors was then conducted during fieldwork surveys and interviews, updated from 2010 to 2014 and supplemented with various resources (reports, interviews and archives). This allowed the production of maps of the main contemporary art industries in Bombay with the ambition to enhance the clustering of activities in certain areas of the metropolitan area.

13. On the division of labor in cinema production and its mapping, see the research project initiated by Madhusree Dutta with Majlis and KRVIA "Project Cinema City", http:// projectcinemacity.com/

\section{ABSTRACTS}

Considering the context of the economic liberalization in India since the 1980's and the growing insertion of contemporary Indian art scene in the global art system, this article aims to analyze the reorganization of artistic production at the scale of Bombay metropolitan territory. Three main aspects will be analyzed: the historical development of an art district in the south of the city, the recent changes in the mapping of contemporary art industry and the new territories of contemporary art production. The aim is to deconstruct the territorial hierarchy imposed by the idea of the "art district", highlight polycentric configurations and the diversity of spaces and interactions that contribute to the dynamism of the art scene.

Dans le contexte de la libéralisation économique de l'Inde depuis les années 1980 et de la croissante insertion de la scène artistique indienne dans le système mondialisé, cet article a pour ambition d'analyser la réorganisation de la production artistique en Inde et plus particulièrement à l'échelle de la métropole de Bombay. Trois principaux aspects seront analysés : l'émergence d'un district artistique dans le sud de la ville, les changements récents dans la géographie de l'industrie de l'art contemporain et les territoires de la production artistique. 
L'objectif est de déconstruire la hiérarchie territoriale imposée par l'idée du district artistique et de mettre en évidence une organisation polycentrique à l'échelle de la métropole, la diversité des espaces et des interactions qui contribuent au dynamisme de la scène artistique.

INDEX

Keywords: Art district, art industry, territory, artists, Bombay, India

Mots-clés: district artistique, industrie de l'art, territoire, artistes, Bombay, Inde

\section{AUTHOR}

\section{CHRISTINE ITHURBIDE}

CESSMA laboratory, Paris Diderot, UMR 245/in co-supervision with the Centre for Study of Regional Development (CSRD), Jawaharlal Nehru University, Delhi, christine.ithurbide@gmail.com 